\title{
Community-Driven Operational Grievance Mechanisms
}

\author{
Jonathan KAUFMAN* and Katherine McDONNELL**
}

Keywords: community-led grievance mechanisms, human rights remedy gap, Myanmar, Third Pillar, UN Guiding Principles

\section{INTRODUCTION}

Just an hour south of Yangon, in an otherwise unremarkable area of farmland and small towns along the Bago River, lies an expansive enclosure of high fences, cleared land, and billboards. This is Thilawa, one of Myanmar's first Special Economic Zones (SEZ). As Phase One-a 400-hectare light manufacturing development with investment commitments from dozens of companies - nears completion, Thilawa is shaping up to be either a flagship economic development project or an unmitigated disaster, depending on whom you ask. For many of the hundreds of locals who have been displaced to make way for new factories, Thilawa has been synonymous with loss of land and livelihoods; the project continues a pattern of government intimidation and neglect that is only too familiar. To the Myanmar Government, JICA (the Japanese development co-operation agency that is backing the project), and potential investors, Thilawa is a clear win for Myanmar and its people. For them, the SEZ is a ticket to a better life for the displaced villagers who need little more than transitional assistance until they can find employment with the incipient industries that will populate the SEZ.

Stung by international criticism and facing a complaint directed at its internal accountability office, JICA has triggered a review of the Thilawa project, with a special emphasis on the impact on local livelihoods and the procedures for community engagement. A centrepiece of this review is the establishment of a grievance mechanism - an internal, project-level process for hearing and resolving community complaints. But it will be a real challenge for the displaced people of Thilawa to trust officials and investors to handle the real, rights-based issues that underlie community discontent, given Myanmar's history of conflict and abuse.

This article describes a new way to approach grievance resolution and problemsolving that the displaced residents of Thilawa are pioneering with the co-operation of

* Legal Advocacy Coordinator, EarthRights International.

** Bertha Legal Fellow, EarthRights International. 
EarthRights International (ERI) and other stakeholders: the community-driven operational grievance mechanism (CDOGM). Our model proceeds from a simple premise: if we want dispute resolution processes to promote human rights and succeed in solving thorny problems between companies and the persons affected by their operations, then those processes should be designed and approved by the affected persons - the rights-holders - rather than those who are believed to have caused the problems in the first place.

\section{The Remedy GaP}

When human rights abuses occur, states are obligated to '[m]ak[e] available adequate, effective, prompt and appropriate remedies' for the benefit of the victims. ${ }^{1}$ The United Nations' Office of the High Commissioner for Human Rights (OHCHR) emphasizes that 'in adopting a victim-orientated perspective, the international community affirms its human solidarity with victims ... as well as with humanity at large'.2

The UN Guiding Principles on Business and Human Rights (UNGPs) provide an internationally accepted framework for the responsibilities and obligations of states and companies with respect to the human rights impacts of business operations. ${ }^{3}$ The Third Pillar of the UNGPs, which focuses entirely on access to remedy, describes three different types of remedial mechanisms: (i) state-based judicial remedies; (ii) state-based non-judicial remedies, and (iii) non-state-based, non-judicial grievance mechanisms. Taken together, these should 'form the foundation of a wider system of remedy'. 4

This third category of remedial mechanisms includes operational-level grievance mechanisms (OGMs). OGMs are established at the site level to handle complaints from workers, community members, and other stakeholders. Generally, OGMs are designed to respond to complaints through dialogue and are conceived as serving two important functions: to assist companies in learning about negative impacts, and to prevent escalation by providing a way for companies to provide remedies early and directly. OGMs may also serve a third purpose: providing an avenue for victims to find a remedy in contexts where the courts or other state-based remedial systems are unavailable or unable to respond.

The majority of existing grievance mechanisms are designed and implemented primarily by the target companies themselves - a clear conflict of interest. OGM users are often frustrated with these mechanisms, both in terms of process and outcome. For example, Barrick Gold established an OGM in Papua New Guinea to provide remedies to victims of rape by security guards at the company's Porgera Mine. In designing its OGM, Barrick consulted with human rights experts and women's advocates but did not engage in a participatory process with victims or their representatives. Many female beneficiaries told ERI that they were dissatisfied with the procedures-which they considered to be confusing and disrespectful—and the remedy offered, which they saw

\footnotetext{
1 UN General Assembly Res 60/147, Annex, para 13, A/RES/60/147/Annex (16 December 2005) (Obligation to respect, ensure respect for and implement international human rights law and international humanitarian law).

2 Ibid, at para 11.

3 Human Rights Council, 'Guiding Principles on Business and Human Rights: Implementing the United Nations "Protect, Respect and Remedy” Framework', A/HRC/17/31 (21 March 2011) 28-31.

4 Ibid, at 28.
} 
as both insufficient and culturally inappropriate. In addition, the OGM was criticized for a provision that required beneficiaries of OGM remedies to sign legal waivers forgoing future civil actions. 5

In Thilawa, many villagers already have negative experiences with top-down remedial processes. The project's Resettlement Action Plan, which was designed by JICA and the local government, has deprived them of their lands without adequate compensation or restitution and exposed them to intimidation at the hands of local government officials. Attempts to engage directly with investors and the SEZ Management Committee have been largely unsuccessful, and a formal objection that they filed with JICA was a bureaucratic disappointment. One villager told ERI, 'We are farmers, but even we know what's fair. The law is biased'. 6

The lack of concrete remedies that OGMs offer is a common source of discontent and contributes to OGMs' failure to meet international standards on the right to a remedy. Many users feel that company-led mechanisms do not actually resolve complaints, ${ }^{7}$ either because they do not provide a remedy at all, or because they provide a remedy that is inappropriate to the situation and their culture. For example, women at Porgera told ERI that in their country, claims of violence are resolved through payment of pigs or money, and that nothing short of this would be adequate for rape victims and their communities to feel respected. Barrick's OGM, however, offered medical and psychological care, school fees, and small grants to purchase baby chickens and used clothing that women could sell in the market. In the local cultural context, these forms of assistance constituted development aid but not a remedy for rape. Similarly, stakeholders affected by BP's Baku-Tbilisi-Ceyhan Pipeline project expressed their dissatisfaction with mitigation measures that were not 'appropriate to local needs or the problem being addressed'. For example, 'instead of reconstructing ... damaged irrigation channels BP has built a kindergarten in the village'.

\section{A RIGHTS-BASED APPROACH}

The CDOGM model proposed here is situated in a broader movement to design rightsholder-driven initiatives in the business and human rights sphere. While stakeholder engagement has long been a byword of successful and robust measures to prevent, mitigate, and remedy human rights abuse, the rise of rights-holder-driven initiatives goes further by emphasizing the agency of communities and other affected stakeholders to prevent and remedy violations of rights by business operations.

Community-led Impact Assessments. The UNGPs (and the laws of most nations) instruct companies to identify and make plans to mitigate the impacts that their

\footnotetext{
5 See, e.g., Press Release, EarthRights International, 'Survivors of Rape by Barrick Gold Security Guards Offered "Business Grants" and "Training" in Exchange for Waiving Legal Rights' (21 November 2014), http:// www.earthrights.org/media/survivors-rape-barrick-gold-security-guards-offered-business-grants-and-training-exchange (accessed 22 August 2015).

6 ERI personal interview with Thilawa farmer, in Thilawa, Myanmar (9 March 2015) (on file with author).

7 Stichting Onderzoek Multinationale Ondernemingen (SOMO), 'Using Grievance Mechanisms: Accessibility, Predictability, Legitimacy and Workers' Complaint Experiences in the Electronics Sector' (2014) 8-9.

8 International Institute for Environment and Development, Dispute or Dialogue?: Community Perspectives on Company-led Grievance Mechanisms (2013) 59.
} 
involvement in a project may occasion. Community Environmental Impacts Assessments ${ }^{9}$ provide a means for rights-holders-and not just the company or its consultants - to participate in the identification and mitigation of the environmental and social impacts that a project is likely to cause. Community-led Human Rights Impact Assessments provide analysis specifically targeted at the human rights impacts of a potential project. ${ }^{10}$ Through these initiatives, the community is able to shape the way in which a project is conceived in a way that is not possible when it is merely one of a number of consulted parties.

Community-designed Impact and Benefit Agreements. Impact and Benefit Agreements (IBAs) are formal contracts between companies and communities that set forth legally-binding commitments on the ways in which the community will benefit from the company's project. The IBA Community Toolkit offers comprehensive guidance for communities on negotiating and implementing IBAs, as an alternative to accepting IBAs proposed by companies. The community-based approach ensures that the agreements are negotiated, drafted, and implemented in a way that meets the needs of the community. ${ }^{11}$

Community-driven FPIC. Some communities have appropriated the language and tools of free, prior, and informed consultation (FPIC) to initiate their own consultations on contentious projects, even when the state has failed to support or even actively opposed their initiative. These exercises have helped to unite indigenous activists in Guatemala and transformed communities' conceptions of their rights, even where they have failed to actually stop projects. ${ }^{12}$

Fair Food Program. The most fully developed of the rights-holder-driven models is the Coalition of Immokalee Workers' Fair Food Program, a worker-driven initiative in the US developed by workers on Florida tomato farms. ${ }^{13}$ The centrepiece of the program is a worker-drafted Code of Conduct to which tomato farms must adhere if they want to sell to participating tomato buyers. This worker-driven social responsibility program is designed, monitored, and enforced by the workers and includes regular peer education and trainings. ${ }^{14}$ This model, which has successfully eliminated some of the worst forms of labour abuse and sexual exploitation of workers in an area renowned for governance gaps, has been publicly praised by the UN Working Group on Business and Human Rights. ${ }^{15}$

\footnotetext{
9 See, e.g., Environmental Law Alliance Worldwide, Guidebook for Evaluating Mining Project EIAs (2010).

10 See International Federation for Human Rights, 'Community-Based Human Rights Impact Assessments' (14 July 2011), https://www.fidh.org/International-Federation-for-Human-Rights/globalisation-human-rights/businessand-human-rights/7502-community-based-human-rights-impact-assessments (accessed 22 August 2015); Oxfam America, 'Community-Based Human Rights Impact Assessment Initiative', http://policy-practice.oxfamamerica.org/ work/private-sector-engagement/community-based-human-rights-impact-assessment-initiative/ (accessed 22 August 2015).

11 Ginger Gibson and Ciaran O'Faircheallaigh, IBA Community Toolkit: Negotiation and Implementation of Impact and Benefit Agreements (2010) 12.

12 Jennifer Costanza, 'Indigenous Peoples' Right to Prior Consultation: Transforming Human Rights From the Grassroots in Guatemala' (June 2015) 14 Journal of Human Rights 260.

13 See Fair Food Program, http://www.fairfoodprogram.org (accessed 22 August 2015); Coalition of Immokalee Workers, http://ciw-online.org (accessed 22 August 2015).

14 Fair Food Program, ibid.

15 UN OHCHR, 'Statement at the End of Visit to the United States UN Working Group on Business and Human Rights, Washington DC' (1 May 2013), http://www.ohchr.org/EN/NewsEvents/Pages/DisplayNews.aspx?NewsID=13284\& LangID $=\mathrm{E}$ (accessed 22 August 2015).
} 


\section{The Thilawa Pilot CDOGM}

Whereas community-led IBAs and HRIAs put communities in the driver's seat for the process of identifying and mitigating harms and extracting benefits, CDOGMs also ensure that the community perspective is central to remedial processes. This model reinforces the position that remedy is not a gift bestowed on a community from a charitable company, but rather the most basic right of affected stakeholders because it secures and ensures the realization of all other substantive human rights. In order to develop and propagate the community-driven OGM model, ERI is implementing a threepart strategy including a CDOGM Toolkit, a pilot project, and a series of expert convenings and workshops.

\section{A. CDOGM Toolkit}

ERI is developing a set of materials that can help communities and their civil society allies design and implement their own community-driven OGMs. These materials include:

- Foundational Principles drawn from international standards on the right to a remedy, international human rights instruments, the UNGPs, and FPIC;

- Practice Points that offer pragmatic advice on the drafting and negotiation of OGM agreements; and

- A Procedural Toolkit with models for the various elements that communities will need to consider as they develop a design and implementation strategy for their own OGMs.

\section{B. The Thilawa Pilot}

In November 2014 ERI began to collaborate with Thilawa community members to develop the preliminary concept for a pilot CDOGM. ERI's team members and partners in Myanmar have long-standing connections with the community, which are a key factor in the success of the pilot. Together, ERI's US and Myanmar staff are providing materials, conducting training and workshops, and advising the Thilawa residents on an advocacy and engagement strategy. With our assistance, villagers are developing a detailed OGM design proposal, which will serve as the basis for negotiation with other stakeholders.

Initial conversations with the Myanmar government, international partners, and Thilawa's corporate investors have been cautiously positive. So far, all stakeholders have expressed that they are willing and receptive to incorporate the community-driven OGM model into their overall plans for stakeholder engagement. The role of these stakeholders and the extent of their participation in the design process, however, will be decided by the community in the full knowledge that deeper involvement by external stakeholders may increase buy-in but may also dilute their voice and level of control over the mechanism.

\section{Expert Convenings}

In partnership with the Centre for Research on Multinational Corporations (SOMO), ERI has convened two expert workshops to discuss the feasibility of the CDOGM model. 
Participants came from a number of fields related to dispute resolution, indigenous issues, business and human rights, and grassroots organizing, and offered their insight, examples, critiques, and questions to help guide the development of the model. ERI has published meeting reports for both of these convenings.

\section{Reflections and Conclusion}

So far, OGM design has been complex and difficult for members of subsistence communities, whose everyday focus is necessarily on more immediate needs than on the abstract aspects of complaints procedures. However, we have observed that villagers can easily grasp the importance of fair process for the protection of their fundamental rights, and many may have experience with formal or non-formal bureaucratic processes that have felt abusive and disempowering. At Thilawa, at least, community members have been eager to exercise the power to create their own vision of a just process, and to teach the CDOGM methodology to their neighbours and peers. The experience of designing an OGM has taken on the nature of a basic civics lesson for people who have never before perceived that they can shape the political structures and the means of obtaining justice in their own community.

As the pilot proceeds, we have observed that it will be easier for the OGM process to address some issues than others. The Myanmar Government has thus far opposed any attempt to question the land confiscations underlying the problems that the Thilawa villagers face. This presents an immense challenge and, to a certain extent, reflects the difficult reality that because OGMs often rely on the goodwill of companies or governments, buy-in from company-side stakeholders is easier to obtain when the OGM addresses only issues that those parties are willing to consider. But counterexamples do exist, such as the CIW's Fair Food Program, through which workers forced tomato growers to confront highly controversial issues through legal action and direct public pressure. More broadly, though, it may suggest that OGMs will most often be used to address prospective rights violations, and only in special cases will they serve to reopen past grievances.

Much else remains unclear. We do not yet know if the corporate and government stakeholders at Thilawa will accept the community members' proposed design. Moreover, even if a design is successfully adopted, communities that have designed grievance mechanisms will need to maintain a long-term commitment to implementing, overseeing, adjusting, and perpetuating the mechanism through peer-to-peer teaching and review.

That said, the positive reception that the CDOGM model has received from all stakeholders gives reason to hope that community-driven grievance mechanisms will prove not only feasible, but preferable as a means to foster a long-term, sustainable, problem-solving environment at corporate project sites in which affected communities have the agency and leverage to protect their human rights and seek remedies when those rights are not respected. 